\title{
Okul Öncesi Çocuklarda Ameliyat Sonrası Ağrı Ölçeği: Türkçe Geçerlilik ve Güvenirliliği
}

\section{Postoperative Pain Scale in Preschool Children: Validity and Reliability of Turkish}

\author{
Tufan Aslı Sezer (0000-0003-2423-3725), Figen Işık Esenay (0000-0001-7576-6500),
} Gülçin Korkmaz (0000-0002-5447-2164)

Ankara Üniversitesi Hemşirelik Fakültesi, Hemşirelik Bölümü, Ankara, Türkiye

\begin{abstract}
Anahtar kelimeler
Ağrı, okul öncesi çocuk, ölçek, geçerlilik, güvenirlik
\end{abstract}

\section{Keywords \\ Pain, preschool children, scale, validity, reliability}

Geliş Tarihi/Received : 02.02.2021

Kabul Tarihi/Accepted : 11.02.2021

DOI:10.4274/jcp.2021.0012

Yazışma Adresi (Sorumlu Yazar)/Address for Correspondence:

PhD. Tufan Aslı Sezer, Ankara Üniversitesi Hemşirelik Fakültesi, Hemşirelik Bölümü, Ankara, Türkiye
$\ddot{\mathbf{O} z}$

Giriş: Bu çalışmada, ülkemizde okul öncesi dönemde (1-5 yaş) olan çocukların ameliyat sonrası ağrının değerlendirilmesi için uygun geçerli ve güvenilir bir ölçek bulunmaması göz önüne alınarak ameliyat sonrası ağrı değerlendirme araçlarından biri olan Okul Öncesi Çocuklarda Ameliyat Sonrası Ağrı Ölçeğinin (The ToddlerPreschooler Postoperative Pain Scale-TPPPS) Türkçe geçerlilik güvenirlilik çalışmasının yapılarak kliniklerde hemşirelere ve araştırmacılara kazandırılması amaçlanmıştır.

Gereç ve Yöntem: Çalışma metadolojik nitelikte olup, Ankara Üniversitesi Cebeci Çocuk Hastanesi Çocuk Cerrahi servisinde Nisan-Temmuz 2019 tarihleri arasında (1) 1-5 yaş aralığında olan, (2) çocuk cerrahi kliniğinde ameliyat olmuş ve postop ilk 1 saat içinde olan, (3) ebeveyni çalışmaya katılmaya gönüllü olan çocuklar alınmıştır. Çalışmaya dahil edilme kriterlerini karşılayan çocukların ebeveynlerinden bilgilendirilmiş onamları alınmıştır. Çalışmanın verileri Tarbell ve ark. (1992) geliştirdiği “Okul Öncesi Çocuklarda Ameliyat Sonrası Ağrı Ölçeği”, FLACC (Face, Legs, Activity, Crying, Consolability) ve "Sosyo demografik Bilgi Formu" ile toplanmıştır. Hastaların post-op 0., 15. ve 30. dakikalardaki ağrı düzeyleri TPPPS ve FLACC ölçekleri kullanılarak değerlendirilmiştir. TPPPS Türkçe formunun geçerlilik çalışması kapsamında, önce ölçeğin dil geçerliliği yapılmış daha sonra içerik geçerliliği için uzman görüşleri değerlendirilmiştir. Güvenilirlik çalışması kapsamında ise, iç tutarlılık kat sayısı ve Paralel Test-Hali hazır güvenirliliği incelenmiştir.

Bulgular: Çalışmanın sonuçlarına göre, TPPPS'nin iç tutarlılık güvenirlik kat sayısı 0,70'in üzerinde ve FLACC ile yüksek derecede uyumlu bulunmuştur.

Sonuç: TPPPS ölçeği, okul öncesi dönemde (1-5 yaş) olan çocukların ameliyat sonrası ağrılarının değerlendirilmesi için geçerli ve güvenilir bir araçtır.

\begin{abstract}
Introduction: There is the lack of a valid and reliable scale suitable for the evaluation of postoperative pain in preschool children (1-5 years old) in Turkey. We aimed to examine the validity of the Postoperative Pain Scale in preschool Children which is one of the postoperative pain assessment tools, nurses and researchers in clinics.

Materials and Methods: The study is methodological and Ankara University Cebeci Children's Hospital Pediatric Surgery Department between April-July 2019. Informed consent was obtained from

the parents of the children who met the inclusion criteria which was (1) 1-5 years of age, (2) underwent surgery at the pediatric surgery clinic and had postop within the first hour, (3) children whose parents volunteered to participate in the study. Data of the study was collected by Postoperative Pain Scale in Preschool Children, FLACC-(Face, Legs, Activity, Crying, Consolability) and Sociodemographic
\end{abstract}


Information Form. The ain levels of the patients were evaluated at post-op 0,15 and 30 minutes using by TPPPS and FLACC scales. First, the language validity study of the Turkish version of the TPPPS was conducted, then expert opinions were taken for content validity. For reliability analysis, internal consistency coefficient and parallel test-ready reliability were examined.

Results: According to the results of the study, internal consistency coefficient of TPPPS was found over 0.70 and highly compatible with FLACC.

Conclusions: TPPPS is a valid and reliable scale for the assessment of postoperative pain in preschool children.

\section{Giriş}

Evrensel bir deneyim olan ağrıyı; Uluslararası Ağrı Araştırmaları Birliği (International Association for the Study of Pain-IASP) "vücudun belli bir bölgesinden kaynaklanan doku harabiyetine bağlı olan veya olmayan, kişinin geçmişteki deneyimleriyle de ilgili, hoş olmayan emosyonel bir duyum" olarak tanımlanmıştır (1). Çocukluk döneminde yaşanan acı, ağrı ve korku deneyimi, çocukların davranış, beslenme düzenive ailesiileolan etkileşimlerini etkileyebilmekte, yetişkinlik döneminde tıbbi bakım almadan korkma ve kaçınmaya neden olabilmektedir (2). Çocuklar tarafından ağrı, hastalık ve hastane sürecinin en stresli ve en korkulan sonucu olarak görülmektedir $(3,4)$. Cerrahi işlemler dokularda travmaya neden olduğu için işlem sonrasında ağrı yaygın olarak görülmektedir $(5,6)$. Literatürde, çocukların cerrahi işlem sonrasında orta ve şiddetli derecede ağnı deneyimledikleri, etkin olmayan ağrı tedavisinin çocuklarda bulantı ve kusma gibi biyolojik olumsuzluklara, iyileşme sürecinde ve hastanede kalış süresinde uzamaya ve sağlık bakım giderlerinin artmasına neden olduğu bildirilmiştir $(6,7) . \mathrm{Bu}$ nedenle ağrının zamanında ve etkin bir şekilde kontrol altına alınması önemlidir. A ğrının kontrol altına alınabilmesi için ağrı göstergelerinin doğru biçimde değerlendirilmesi gerekmektedir (8). Bunun için çocukların savunucuları olan hemşirelerin, ağrı değerlendirilmesi ve kontrolü konusunda yeterince bilgi, beceri ve deneyim sahibi olması ve uygun değerlendirme ölçütleri ile çocukların ağrılarını değerlendirmesi gerekmektedir.

Çocuklarda ağrı, kendini ifade edebilme süreçlerindeki farklılıklar ve sınırlı iletişim nedeniyle sağlık çalışanları tarafından değerlendirilmesi, ölçülmesi ve yönetimi zor bir durumdur ve genellikle yetersiz değerlendirilmektedir $(5,9,10)$. Çocukların yaşı, gelişim düzeyi, bilişsel becerileri, iletişim becerileri, önceki ağrı deneyimleri ve inançları ağrıyı algılama ve gösterme şekillerini etkilemektedir $(3,4,8)$. Aynı zamanda ağrıya neden olan durumlara göre ağrının özelliği farklı olabileceğinden, farklı durumlar için farklı ağrı ölçeklerine ihtiyaç duyulmaktadır (8). Tüm bu farklılıklar, çocuklarda ağrının değerlendirilmesinde farklı ölçeklere ihtiyaç doğurmaktadır (4). Bu nedenle çocuğun yaşına ve ağrı nedenine özgü ölçekler geliştirilmeli ve kullanılmalıdır. Örneğin bilişsel ve dil gelişimleri yetersiz olan bebeklik döneminde davranışsal özellikleri veya fizyolojik parametreler içeren ölçekler bebeklerin ve yeni doğanların ağrı değerlendirilmesinde yaygın olarak kullanılmaktadır (11). Ülkemizde çocuklarda sıklıkla kullanılan ağrı ölçekleri, FLACC (Yüz, Bacaklar, Hareket, Ağlama, Avutabilme), Görsel Analog Skala (VAS) ve Wong Baker Yüzler Ağrı Ölçeği (WongBaker Faces Pain Rating Scale) yüz skalasıdır. Bu ölçekler görsel ağrı ölçme araçlarıdır ve çocukların sadece yüz ifadeleri değerlendirilmektedir. Ergenlik dönemindeki çocukların ise gelişimleri erişkine yakın olduğundan, özbildirime dayalı görsel ağr1 araçları güvenle kullanılabilir. Oyun ve okul öncesi dönemdeki çocukların ise duygusal, bilişsel ve dil gelişimleri bebeklerden daha iyi olmasına rağmen ergenler kadar yeterli değildir. Bu nedenle okul öncesi çocuklar için davranış değerlendirme ölçekleri yetersiz ve öz bildirim yüz ölçekleri ise uygunsuz kalabilmektedir $(11,12)$. Ağrı, tek boyutlu ve çok boyutlu ağrı değerlendirme araçları ile değerlendirilebilir. Tek boyutlu araçlar, genellikle girişimsel olmayan uygulamalarda ağrı ile ilgili hızlı bilgi almak ve ağrının varlı̆̆ını değerlendirmek için kullanılır. Çok boyutlu araçlar ise ağrıyı duyusal ve duygusal yönüyle açıklamak için kullanılır(8). Ağrının değerlendirilmesinde en güvenilir yöntem olarak öz bildirim ve davranışsal ölçümlerin bir arada kullanılmasını önerilmektedir (4).

Ülkemizde okul öncesi dönemde olan çocukların ameliyat sonrası ağrının değerlendirilmesi için uygun, geçerli ve güvenilir bir ölçek bulunmamaktadır. The Toddler-Preschooler Postoperative Pain Scale (TPPPS), Tarbell ve arkadaşları tarafından 1-5 yaş arası 
çocukların ameliyat sonrası ağrısının değerlendirilmesi için geliştirilmiş, çok boyutlu bir ağrı ölçeğidir. Ölçek, üç davranış kategorisinde (vokal, yüz ve bedensel) ağrı ifadelerini gözlemleyen, basit ve uygulanabilirliği yüksek bir ölçektir (12). Bu çalışmada The ToddlerPreschooler Postoperative Pain Scale (Okul Öncesi Çocuklarda Ameliyat Sonrası Ağrı Ölçeği) ölçeğinin Türkçe geçerlilik güvenirliliğinin test edilmesi amaçlanmıştır.

\section{Gereç ve Yöntem}

\section{Çalışmanın Şekli}

Okul Öncesi Çocuklarda Ameliyat Sonrası Ağrı ölçeğinin geçerlik ve güvenirliğini test etmek amacıyla metodolojik olarak planlanmıştır.

\section{Çalışmanın Yeri ve Zamanı}

Çalışma bir üniversite hastanesinin çocuk cerrahi servisinde Nisan-Haziran 2019 tarihleri arasında gerçekleştirilmiştir. Servis 33 yatak kapasitesine sahiptir. Serviste günde ortalama 15 operasyon yapılmaktadır. Hastalara, ameliyat öncesi anestezi ekiplerince, operasyonun anestezi prosedürüne uygun premedikasyon uygulanmaktadır. Operasyon bitimine yakın, uygulanan oprerasyonun türüne uygun analjezi (Parasetamol veya opioid grubu aneljezikler) uygulanıp, ameliyat sonrası ilk takibin yapıldı $\breve{g}_{1}$ uyandırma alanına alınmaktadır. Hasta, yaklaşık 30 dakika sonra uyandırma alanından servise alınmaktadır. Hastaların ameliyat sonrası ağn değerlendirilmesi servise alındığında, FLACC ölçeği ile yapılmaktadır. Hastanın ağrı değerlendirmesi ölçekten alınan puan 4'ün altında ise üç saatte, 4'ün üzerinde olduğunda ise iki saat aralıklarla yapılmaktadır. Klinikte ameliyat sonrası takip edilen hastalara üç gün süreyle profilaktik olarak 6 saatte bir analjezi uygulaması order edilmektedir.

\section{Çalışma Grubu}

Ölçek çalışmalarında, örneklem büyüklüğünün belirlenmesinde ölçek madde sayısının en az beş, olabilirse on kat1 olması önerilmektedir (13). TPPPS ölçeğinin yedi madde olması nedeniyle göre çalışmanın örneklem büyüklüğü, madde sayısının 8 kat1 olacak şekilde 80 olarak belirlenmiştir. Çalışmanın örneklemini Nisan-Haziran 2019 tarihleri arasında bir üniversite hastanesinin çocuk cerrahi servisinde ameliyat olmuş, çalışmaya dahil edilme kriterlerine uyan 1-5 yaş arasındaki çocuklar oluşturmuştur. Çalışmanın dahil edilme kriterleri; (1) 1-5 yaş aralığında olması, (2) çocuk cerrahi kliniğinde ameliyat olması ve ameliyat sonrası ilk 1 saat içinde olması, (3) ebeveyni çalışmaya katılmaya gönüllü olarak kabul eden çocuklar olarak belirlenmiştir.

\section{Veri toplama araçları}

Çalışmanın verileri sosyo demografik bilgi formu, TPSSS ve FLACC ağrı skalaları ile toplanmıştır.

Sosyo Demografik Bilgi Formu; İlgili literatür doğrultusunda $(11,12,14)$ araştırmacılar tarafından hazırlanmıştır. Çocuğun yaşı, cinsiyeti, tıbbi tanısı, geçmişteki ve mevcut sağlık durumu, daha önce ameliyat geçirip geçirmediği, kullandığ ilaçlar, geçmiş tıbbi öyküsü, geçmiş ağrı deneyimi, ameliyat sırasında aldığ 1 anestezinin türü, ameliyat sonrası analjezi alıp almaması, aldıysa bu analjezik ilacın veriliş yolu ve türünü tanılamaya yönelik sorulardan oluşmaktadır.

Okul Öncesi Çocuklarda Ameliyat Sonrası Ağrı Ölçeği (The Toddler-Preschooler Postoperative Pain Scale-TPPPS); Tarbell ve arkadaşları tarafından (1992) okul öncesi çocukların ameliyat sonrasını ağrısını değerlendirmek için geliştirdikleri bu ölçek vokal ağrı ifadesi, yüz ağrısı ifadesi ve bedensel ağr1 ifadesi şeklinde üç davranış kategorisinde bulunan yedi maddeden oluşmaktadır. $\mathrm{Bu}$ maddeler, hasta anesteziden uyandıktan sonra 6 kez beş dakika aralıklar ile değerlendirilmektedir. Hasta uyursa, gözlemci gözlemlemeyi bırakır. Değerlendirme, gözlem periyodu sırasında ağrı davranışı varsa 1-(bir), mevcut değilse 0-(sıfır) olarak puanlanır. Toplam skor altı değerlendirmenin ortalaması alınarak hesaplanır, skor 0 ile 7 arasında değişmektedir. Puanın yüksek olması ağrının da o kadar şiddetli olduğunu göstermektedir. Ölçeğin toplam üç davranış kategorisinde Cronbach alfa katsayısı 0.88 olarak bulunmuştur (12).

FLACC (Face, Legs, Activity, Crying, Consolability) Ağrı Ölçeği; Merkel ve arkadaşları tarafından 1997 yılında geliştirilen ağrı değerlendirme ölçeği ile 3-7 yaş arası ameliyat sonrası dönemde kendi ağrısını ifade edemeyen ve iletişim kurulamayan çocuklarda beş davranışsal kategorinin (Yüz ifadesi, bacak hareketleri, aktivite, ağlama, teselli edilirlik) değerlendirilmesi ile ölçüm yapılmaktadır (15). Akut süreçlere bağlı ve ameliyat sonrası ağrının hastanede 
değerlendirilmesinde kullanılan ölçeğin Türkçe dil geçerliliği Şenayli ve ark. (2006) tarafından yapılmıştır (16). Değerlendiriciler arası uyum 2 yönlü çapraz tabakalandırma yöntemi ile değerlendirilmiş ve değerlendiriciler arası uyumluluk oranı için kappa değerleri incelenmiştir. Kappa değerlerinin 0,75 ve üzeri bulunması tam uyum olarak kabul edilmiş ve ölçeğin ameliyat sonrası dönemde ağrının değerlendirilmesinde başarılı olduğu saptanmıştır (16). Ölçek yüz, bacak, hareket, ağlama, aktivite durumu ve teselli edilebilirlik derecesi şeklinde beş unsurdan oluşmaktadır. Ölçek uyanık olan hastalarda 1 ve 5 dakika arası süre ile gözlem yapılarak kullanılmaktadır. Her bir madde 0-2 arasında puanlanmaktadır. 0 puan hastanın rahat olduğunu; 1-3 puan hafif ağrı olduğunu; 4-6 puan orta derece ağrı olduğunu ve 7-10 puan şiddetli ağrıyı ifade etmektedir. Eğer yüzde belirgin ifade yoksa, bacak normal pozisyonda ise, aktivite normal ise, ağlama yok ise, hoşnut veya rahat ise, her bir unsur 0 ile puanlanır. Eğer yüz buruşuk veya kaş çatık ise, bacak hareketleri gergin ise, aktivite gergin ve baş ileri geri hareket eder ise, ağlama inilti şeklinde ise, ilgi ve dokunma ile sakinleşme var ise, her biri için 1 puan verilir. Eğer yüz de çene titremesi ve dişlerini vurma var ise, bacaklar hareketli ise, sert ve burkulan tarzda hareket var ise, çı̆̆lık atma ve hıçkırma ağlama var ise, teselli olması zor ise, her biri için 2 puan verilir (16).

\section{İslem}

TPPPS ölçeğinin Türkçeye uyarlama sürecinde ilk olarak, ölçeğin geliştiricisi Sally E. Tarbell ile iletişime geçilmiş ve ölçeğin uyarlamasına ilişkin izin alınmıştır.

Çalışma iki aşamada gerçekleştirilmiştir. İlk aşamada ölçeğin geçerliği incelenmiş daha sonra güvenirliğine ilişkin analizler yapılmıştır. Geçerlik aşamasında, ölçek dil geçerliği ve kapsam geçerliği için uzman görüşüne sunulmuştur. Güvenirlik aşamasında ise, ölçeğin iç tutarlılık katsayısı hesaplanmış ve paralel test güvenirliği yapılmıştır.

Bir araştırmacı haftanın iki günü saat 8-16 saatleri arasında klinikte bulunarak, klinikte çalışan bir hemşire yardımıileçalışmayadahiledilmekriterlerinikarşılayan pre-operatif çocukları belirlemiş, çocuk ve ebeveynleri araştırma hakkında bilgilendirerek, aydınlatılmış onamlarını almıştır. Ameliyat öncesi dönemde ebeveyn tarafından tanımlayıcı veri formu doldurulmuştur. Sonrasında çocuk, klinik ekibi tarafından, kliniğin prosedürüne uygun şekilde ameliyata hazırlanmış ve gönderilmiştir. Ameliyat sonrası ağrıları TPPPS ve FLACC ölçeği ile değerlendirilmiştir. Çocuk, ameliyat sonrası uyanmaya başladığı andan itibaren, ölçeğin uygulanması konusunda eğitilmiş bir klinik hemşire tarafından, TPPPS ölçeğinde yer alan 7 ağnı davranışı açısından $30 \mathrm{dk}$ boyunca gözlenmiş, on beş dakikalık aralıklarla (3 kez) puanlanmıştır. Eğer çocuk bu sırada uyumuş ise değerlendirme sona erdirilmiştir. Tarbell ve arkadaşlarının belirttiği gibi, hasta uyandığında değerlendirme yeniden başlatılmıştır. FLACC ağrı ölçeği ise, ameliyat sonrası dönemde uyanmaya başladığı andan itibaren ilk 30 dakika, on beş dakikalık aralıklarla (3 kez) uygulanmış ve puanlanmıştır. Ameliyat sonrası 30. dakikada değerlendirme sona ermiş̧tir. Değerlendirmeler sonrası hastanın ağrı puanı 4 ve üzerinde ise, kliniğin ağrı yönetim protokolüne uygun olarak ağrı kontrolü uygulamaları klinik ekibi tarafından yapılmıştır.

\section{Verilerin Analizi}

Verilerin istatistiksel analizinde Statistical Package for Social Sciences (SPSS-15.0 versiyon) paket programı kullanılmıştır. Çalışmanın sosyo demografik bilgilerinin değerlendirilmesinde tanımlayıcı istatistiklerden sayı ve yüzde kullanılmıştır. TPPPS ölçeğinin iç tutarlılık katsayısı için Cronbach alfa katsayı hesaplanmıştır. TPPPS ve FLACC ölçekleri arasındaki paralel test güvenirliği incelemek için Pearson korelasyon analizi kullanılmıştır. Elde edilen sonuçlar \% 95 güven aralığında, $\mathrm{p}<0,05$ anlamlılık düzeyinde değerlendirilmiştir.

\section{Çalışmanın Etik Yönü}

Çalışmanın yapıldı $\breve{g} 1$ hastaneden gerekli idari izin alınmıştır. Çalışmanın protokolü Üniversite Klinik Etik Kurulu tarafından onaylanmıştır (28.05.2019 tarih, 34986 sayılı ve karar no: 220). Çalışma için TPPPS ölçeğini geliştiren Sally E. Tarbell'den e-posta aracılığ1 ile ölçeğin kullanılabilmesi için gerekli izin alınmıştır. Çalışma kapsamına alınan çocuklar ebeveynlerine çalışma hakkında bilgi verilmiş ve ebeveynlerin yazılı aydınlatılmış onamları alınmıştır. Çalışmanın tüm aşamaları Helsinki Bildirgesi’nin ilkelerine uygun gerçekleştirilmiştir. 


\section{Bulgular}

\section{Tanımlayıcı istatistikler}

Çalışma kapsamına alınan çocukların yaş ortalaması 3,23 $\pm 1,32$ olup, \%66,3'ü erkektir. Çocuklar en fazla akut apandisit $(n=15)$, hipospadias $(n=12)$ ve sünnet $(n=11)$ ameliyatları nedeniyle cerrahi servisinde yatmaktadır. Hastaların tamamı genel anestezi ile ameliyat olmuştur. Ameliyat sonrası analjezi alan 69 çocuğun (\%86,3), \% 77,5'i intravenöz yol ile diğerleri ise oral yoldan Parasetamol ilaç almışlardır. Çalışmaya alınan çocukların diğer tanımlayıcı özellikleri Tablo 1 'de yer almaktadır. TPPPS ölçeği ortalama puanı $1,88 \pm 1,05$, FLACC ortalama puan $13,36 \pm 1,94$ 'dür (Tablo 2).

\section{Geçerlik ve Güvenirlik Analiz Sonuçları}

TPPPS ölçeğinin geçerlik ve güvenirliğinin test edilmesi için aşağıdaki analizler gerçekleştirilmiştir.

\section{Ölçek geçerlilik aşaması}

Dil Geçerliliği; Ölçeğin dil geçerliliği için öncelikle kaynak dili İngilizce olan TPPPS ölçek maddeleri çeviri alanında uzman üç kişiye verilerek hedef dil olan Türkçe'ye çevrilmiştir. Üç uzman çevirilerini birbirlerinden bağımsız yapmışlardır. Daha sonra çeviriler araştırmacılar tarafından karşılaştırılarak her bir madde için en uygun çeviri belirlenmiş ve Türkçe ön-ölçek oluşturulmuştur. Bir sonraki aşamada, ölçek iki dil uzmanı tarafından ana diline (İngilizce) çevrilmiştir. Son olarak, elde edilen ölçek maddelerinin anlam değişikliği olup olmadığı değerlendirilmiş ve her bir maddeyi en iyi ifade eden çeviriler seçilerek ölçeğin Türkçe son versiyonu oluşturulmuştur.

\section{İçerik/Kapsam Geçerliliği}

TPPPS ölçeğinin Türkçe formu, uzman görüşü alınarak kapsam geçerliliği açısından incelenmiştir. Çevirisi tamamlanan ölçeğin son hali, alanında uzman 5 kişiye (Çocuk cerrahi hemşiresi, çocuk cerrahisi hekimi, çocuk sağlığı hastalıkları hemşireliği öğretim üyesi) gönderilmiş ve maddelerin uygunluğunun değerlendirilmesi istenmiştir. Uzmanlardan alınan görüşlerin değerlendirilmesinde İçerik/Kapsam Analizi İndeksi (Content Validity Index-CVI) kullanılmıştır. Değerlendirmede uzmanlardan, ölçeğe ilişkin her bir maddeyi "uygun değil çıkartılmalı=1", "Uygun ancak düzeltilmeli (maddelerin/ifadelerin uygun şekle getirilmesi gerekli) =2", "Uygun=3" şeklinde puanlamaları istenmiştir. Ek olarak her bir maddeye ilişkin uygun gördükleri değişiklik önerilerini yazmaları istenmiştir. Uzman görüşleri toplandıktan sonra her bir madde için uzmanların görüşleri araştırmacılar tarafından tek bir formda birleştirilerek, Lawshe Tekniği dikkate alınarak analizleri yapılmışır (17). Maddelerin kapsam geçerlik puanı Lawshe'nin belirttiği (1975) $\alpha=0,05$ anlamlılık düzeyinde Kapsam Geçerlik Ölçütünün (KGÖ) minimum/kritik değerleri

Tablo 1. Tanımlayıcı Özellikler $(\mathrm{n}=80)$

\begin{tabular}{|c|c|c|c|c|}
\hline & & \multicolumn{2}{|l|}{ Sayı (n) } & Yüzde (\%) \\
\hline \multicolumn{2}{|l|}{ Yaş } & \multicolumn{2}{|c|}{$3,23 \pm 1,32$ (min:1 $\max : 5)$} & \\
\hline $\begin{array}{l}\text { Cinsiyet } \\
\text { Kız } \\
\text { Erkek }\end{array}$ & & $\begin{array}{l}27 \\
53\end{array}$ & & $\begin{array}{l}33,7 \\
66,3\end{array}$ \\
\hline $\begin{array}{l}\text { Daha önc } \\
\text { Evet } \\
\text { Hayır }\end{array}$ & umu & $\begin{array}{l}28 \\
52\end{array}$ & & $\begin{array}{l}35 \\
65\end{array}$ \\
\hline $\begin{array}{l}\text { Ameliyat } \\
\text { Evet } \\
\text { Hayır }\end{array}$ & a durumu & $\begin{array}{l}69 \\
11\end{array}$ & & $\begin{array}{l}86,3 \\
13,8\end{array}$ \\
\hline \multicolumn{5}{|c|}{ Tablo 2. Ölçeklerin Puan Ortalamaları } \\
\hline & Ortalama & $0 . \mathrm{dk}$ & $15 . \mathrm{dk}$ & $30 . \mathrm{dk}$ \\
\hline TPPPS & $1,88 \pm 1,05$ & $3,03 \pm 1,73$ & $1,77 \pm 1,34$ & $0,85 \pm 1,08$ \\
\hline FLACC & $3,36 \pm 1,94$ & $5,42 \pm 2,75$ & $3,17 \pm 2,13$ & $1,52 \pm 1,80$ \\
\hline
\end{tabular}


baz alınarak hesaplanmış ve uzman sayısı beş olduğu için KGÖ kritik değeri 1 olarak alınmıştır (18). Kapsam geçerlik ölçütü, bir maddenin ölçekte kalması yönünde görüş bildiren uzman sayısının, maddeye ilişkin görüş belirten uzman sayısının yarısına oranının 1 eksiği ile elde edilmektedir. KGÖ değeri 0'a eşit ya da negatif ise bu madde ya da maddeler hesaplamaya alınmadan çıkarılmaktadır. KGÖ değerleri pozitif olan her bir madde için anlamlılıkları 0,05 düzeyinde test edilir (18). KGÖ'nün tespitiyle maddeler ölçeğe dâhil olmak üzere tanımlandıktan sonra, Kapsam Geçerlik İndeksi (KGI) testin tamamı için hesaplanmıştır. Bu durumda ölçekte yer almasına karar verilen maddelerin KGÖ değerlerinin ortalaması hesaplanarak KGI değeri elde edilir. Uzmanlardan elde edilen görüşler doğrultusunda her bir madde için "uygun" görüşü verildiği için, yapılan hesaplamalar sonuncun TPSSS ölçeğinin KGİ değeri 1 olarak bulunmuştur. Buna göre TPSSS ölçeğinin kapsam geçerliği istatistiksel olarak anlamlı bulunmuştur.

\section{Ölçeğin Güvenirlik aşaması}

TPPPS ölçeğinin Cronbach alfa iç tutarlılık güvenirlik katsayısı 0,77 olarak bulunmuştur. TPPPS ölçeği ile birlikte FLACC ağrı ölçeği, aynı hasta grubuna eş zamanlı uygulanmış ve paralel test korelasyon düzeyi incelenmiştir. İki ölçeğin ortalama puanları arasında, her üç ölçüm zamanında $(0,, 15$. ve 30. dk) da anlamlı ve güçlü bir ilişkinin olduğu saptanmıştır $(p<0,01)$ (Tablo 3). Elde edilen bu sonuçlar TPPPS ölçeğinin güvenirliğine kanıt olarak değerlendirilmiştir.

\section{Tartışma}

Bu çalışmada ameliyat sonrası ağrı değerlendirme araçlarından biri olan Okul Öncesi Çocuklarda
Ameliyat Sonrası Ağrı Ölçeği’nin Türkçe geçerlilik güvenirlilik çalışmasının yapılarak kliniklerde ve bilimsel çalışmalarda kullanılabilecek bir ölçme aracının literatüre kazandırılması amaçlamıştır. $\mathrm{Bu}$ doğrultuda ölçeğin geçerliliğini test etmek için dil geçerliliği ve kapsam geçerliliği, güvenirliğini test etmek için ise paralel test güvenirliği ve iç tutarlılık katsayısı kullanılmıştır.

Bir ölçeğin uyarlama aşamasında en önemli işlemlerden birinin çeviri süreci olduğu bilinmektedir $(19,20)$. Bu süreç bir dilden diğerine yapılan mekanik bir çeviriden öte, ölçek maddeleri ile ölçülen yapının kültürel uyarlamasını içermektedir. Çeviri sürecinin doğru tamamlanması için temel adımlarının ele alınması önemlidir. Bu adımlardan en önemlisi dil alanında uzman ve çevrilen konuya ilgili çevirmenlerden yararlanılması, en az iki çevirmen kullanılması ve her iki çeviri üzerinde düzeltmeler yapacak uzmanların yer almasıdır (21). Bu çalışmada, dil çevirisi için pediatri hemşireliği ve ağrı alanında uzman öğretim üyeleri seçilmiş ve çevirilerin birbirlerinden bağımsız yapmaları sağlanmıştır. Ölçeğin çeviri sürecinde, ileri ve geri çeviri yöntemleri kullanılmış olup, bu yöntem kültürlerarası ölçek uyarlamalarında sıkça önerilmektedir $(19,20)$. İleri çeviride ölçek, orijinal dilden hedef dile, geri çeviride ise, kaynak dilden hedef dile bir ya da birkaç çevirmen tarafından uyarlanır. Daha sonra farklı çevirmenler hedef dilden kaynak dile geri uyarlama yaparlar. Orijinal ve geri çevirisi yapılmış durumlar karşılaştırılır ve denkliğine karar verilir. Geri çeviri, kaynak ve hedef dil arasındaki anlamsal denkliğin doğrulanabilmesini sağlamaktadır(19). Bu çalışmada, ileri çeviride araştırmacılar ve alanında uzman iki öğretim üyesi ölçeğin maddelerini ana dilinden hedef dil olan Türkçeye çevirisini yapmıştır. Geri çeviride

Tablo 3. Ölçeklerin Korelasyonu

\begin{tabular}{|c|c|c|c|c|}
\hline Ağrı Ölçeği & FLACC 0.dk. & FLACC $15 . \mathrm{dk}$ & FLACC $30 \mathrm{dk}$ & FLACC_Ortalama \\
\hline TPPPS 0.dk & $\begin{array}{l}\mathrm{r}: 0,636 \\
\mathrm{p}: 0,000^{*}\end{array}$ & & & \\
\hline TPPPS 15 dk. & & $\begin{array}{l}\text { r: } 0,783 \\
\text { p:0,000* }\end{array}$ & & \\
\hline TPPPS 30 dk. & & & $\begin{array}{l}\text { r:0,663 } \\
\text { p:0,000* }\end{array}$ & \\
\hline TPPPS_Ortalama & & & & $\begin{array}{l}\text { r :0,813 } \\
\text { p:0,000* }\end{array}$ \\
\hline$* \mathrm{p}<0,01$ & & & & \\
\hline
\end{tabular}


ise ölçek iki farklı dil uzmanına verilerek ölçeğin ana dili İngilizce'ye çevirisi sağlanmıştır.

Ölçek uyarlamalarında, ölçeğin içerik (kapsam) geçerliliği için test maddelerinin ölçülmek istenen davranışı yansitıp yansıtmadığının değerlendirilmesi gerekmektedir $(22,23)$. Ölçeklerde kapsam geçerliliğii, uzman görüşlerine dayanmakta olup, uzmanların ölçek maddelerinin ölçülen duruma uygunluğunu değerlendirilmesiyle gerçekleştirilmektedir (24). Kapsam geçerliliğinde yapılacak hesaplamalarda objektif sonuçlar elde edilebilmesi için uzmanların niteliği ve sayısının (5-40 arası) büyük önem taşıdığı belirtilmektedir (18). Bu çalışmada, ölçeğin Türkçe versiyonu alanında uzman beş akademisyene gönderilerek değerlendirmeleri istenmiştir. Lawshe tekniğine göre yapılan analizler sonucunda kapsam geçerlik ölçütü bir olarak belirlenmiş ve maddelerin hiçbirinin bu değerin altında bir değer almadığ 1 görülmüştür. Buna göre ölçek maddelerinin tamamının ameliyat sonrası ağrı deneyimini ölçmede geçerli olduğu görüşüne varılmıştır.

TPPPS ölçeğinin iç tutarlı̆̆ının değerlendirilmesinde Cronbach alfa değeri hesaplanmıştır. Cronbach alfa değerinin 0,40'ın altında olması ölçeğin "güvenilir olmadığını", 0,40 0,59 arasında olması ölçeğin "düşük güvenirlikte" olduğunu, 0,60-0,79 arasında olması ölçeğin "güvenilir" olduğunu ve " $0,80-1,00 "$ arasında olması da ölçeğin yüksek güvenirlikte olduğunu gösterir $(22,23)$. Bu çalışmada ölçeğin Cronbach alfa değeri 0,77 saptanmış, iyi bir iç tutarlılığa sahip ve güvenilir olduğu söylenebilir. Ölçeğin orijinal dilinde uygulanan çalışmasında ise Cronbach alfa katsayısı $0,88^{\prime} \operatorname{dir}(12)$.

Çalışmada yapılan bir diğer güvenirlik analizi ise paralel test- hali hazır güvenirliliğidir. Yapılan bir derlemede, Türkiye'deki ağrı ölçek çalışmalarının en önemli eksikliğinin, eş zamanlı (paralel) geçerliliğinin ölçülmemesi olarak belirtilmiştir (4). Çalışmamızda, çalışma kapsamına alınan çocuklara farklı bir ölçek eş zamanlı uygulanmış ve ölçek puanları arasında anlamlı ve güçlü bir ilişki olduğu saptanmıştır (Tablo 2). Çalışma sonuçlarına göre, 1-5 yaş arası çocukların ameliyat sonrası ağrı ortalamaları TPPPS puanı 1.88 ile hafif düzeyde, FLACC ise 3.36 ile hafif düzeyde değerlendirilmiştir. TPPPS ölçeğinin, ameliyat sonrası ağrıyı genel bir ağrı ölçeğine (FLACC) benzer değerlendiriyor olması, ölçeğin güvenirliğinin yüksek olduğunu göstermektedir. TPPSS ölçeği ile 1-5,5 yaş arasında olan 167 Tai'li ameliyat sonrası çocuklar ile yapılan bir çalışmada ameliyat sonrası ve analjezi öncesi yapılan değerlendirmelerinde ölçek puanını ortalama 3 (3), 100 çocuk ile yapılan diğer bir çalışmada ise ölçek puanı ortalama 2 (25) olarak bulunmuştur. Ölçeğin geliştirildiği ilk araştırmada TPPSS puanı ortalaması ise 2,1 olarak saptanmıştır (12). Çalışma sonuçlarımız literatürdeki sonuçlar ile benzer nitelikte olduğundan, ölçüm aracının güvenilir olduğu söylenebilir. Ek olarak, TPPPS ölçeğinin kolay uygulanabilmesi, pratik olması ve basit bir puanlama yönteminin olması da ölçeğin tercih edilmesini sağlayabilir (12). Ayrıca Türkiye de yapılan bir çalışmada sağlık çalışanlarının büyük bir bölümünün ağrıyı çocukların davranışsal tepkilerinden değerlendirdiklerini belirtmiştir (4). $\mathrm{Bu}$ açıdan bakıldı ̆̆ında ameliyat sonrası ağrının doğru değerlendirilebilmesi ve çocukların ağrısına yönelik erken müdahale edilebilmesi için çocukların davranışsal tepkilerini içeren TPSSS ölçeği yardımcı olabilir.

\section{Sonuç}

Çalışma sonuçları, TPPPS ölçeğinin, okul öncesi dönemde (1-5 yaş) olan çocukların ameliyat sonrası ağrılarının değerlendirilmesi için geçerli ve güvenilir bir ölçme aracı olduğunu göstermiştir. Ülkemizde bir çok ağrı ölçme aracı olmasına rağmen, ölçme araçlarının bu dönem için uygun olmaması ve ameliyat sonrası çocukların ağrı değerlendirilmesi için spesifik bir ölçeğin bulunmaması nedeniyle bu ölçeğin okul öncesi dönemdeki çocukların ameliyat sonrası ağnı değerlendirilmesine katkı sağlayacağ 1 düşünülmektedir.

\section{Etik}

Etik Kurul Onayı: Çalışmanın yapıldı $\breve{g}$ hastaneden gerekli idari izin alınmıştır. Çalışmanın protokolü Üniversite Klinik Etik Kurulu tarafından onaylanmıştır (28.05.2019 tarih, 34986 sayılı ve karar no: 220).

Çıkar Çatışması: Yazarlar tarafından çıkar çatışması bildirilmemiştir.

Finansal Destek: Yazarlar tarafından finansal destek almadıkları bildirilmiştir. 


\section{Kaynaklar}

1. International Association for the Study of Pain (IASP) (2010). Pain terminology. http://www.iasp-pain.org.

2. Göl İ, Onarıcı M. Nurses' knowledge and practices about pain and pain control in children. J Hacettepe Univ Faculty of Nurs 2015;2(3):20-9.

3. Suraseranivongse S, Santawat U, Kraiprasit K, Petcharatana S, Prakkamodom S, Muntraporn N. Cross-validation of a composite pain scale for preschool children within 24 hours of surgery. Br J Anaesth 2001;87(3):400-5.

4. Bakır E. Çocuklarda A ğrı Değerlendirme ve Ölçekleri: Kültür ve Yaşın Ağrı Değerlendirmesine Etkileri. Turkiye Klinikleri J Nurs Sci 2017;9(4):299-314.

5. Hancı V, Kiraz HA, Ömür D, Yurtlu BS, Arslan Yurtlu D, Alan C. Postoperative pain in children. J Anesthesia Clin Res 2012;3(6):219.

6. Alon E, Knessl P. Prevention and treatment of postoperative pain. Ağrı. 2000;12(3):9-14.

7. Sng OW, Taylor B, Liam JLW, Klainin-Yobas P, Wang W, Hong$\mathrm{Gu} \mathrm{H}$. Postoperative pain management experiences among school-aged children: a qualitative study. J Clin Nurs 2013;22: 958-68.

8. Akcan E, Yiğit R. Prematüre Bebek Ağrı Profili: Türkçe Geçerlilik ve Güvenirliliği. F.Ü.Sağ.Bil.Tıp Derg 2015;29 (3):97-102.

9. Sayar S, Ergin D. Ortopedi Servisinde Yatan Çocuk Hastalarda Ameliyat Sonrası Ağrı Yönetiminde Müziğin Etkisinin İncelenmesi. DEUHFED 2019;12(1):67-73.

10. Hla TK, Hegarty M, Russell P, Drake-Brockman TF, Ramgolam A, von Ungern-Sternberg BS. Perception of pediatric pain: a comparison of postoperative pain assessments between child, parent, nurse, and independent observer. Pediatr Anesth 2014;24:1127-31.

11. Hartrick C, Kovan JL. Pain Assessment Following general Anesthesia Using the Toddler Preschooler Postoperative Pain Scle: A comparative Study. J Clin Anesth 2002;14:411-5.

12. Tarbell SE, Cohen IT, Marsh JL. The Toddler-Preschooler Postoperative Pain Scale: an observational scale for measuring postoperative pain in children aged 1-5. Preliminary report. Pain 1992;50:273-80.
13. Esin NM. Veri Toplama Yöntem ve Araçları \& Veri Toplama Araçlarının Güvenirlik ve Gecerliği. In S. Erdoğan, N. Nahcivan, \& M. N. Esin (Eds.), Hemşirelikte Araştırma Süreç, Uygulama ve Kritik (pp. 216-31). İstanbul, Turkey: Nobel Tip Kitabevleri, 2014.

14. Yasmin R, Akhtaruzzaman AKM, Sarker PC, Ahmed N, Kundu RK, Iqbal KM. Pre-Emptive Analgesia For Postoperative Pain Relief in Children - Role Of Paracetamol. J BSA, 2005;18:1-2.

15. Merkel SI, Voepel-Lewis T, Shayevits JR, Malviya S. The FLACC: A behavioral scale for scoring postoperative pain in young children. Pediatr Nurs 1997;23:293-7.

16. Senayli Y, Ozkan F, Şenaylı A, Bicakci U. Evaluation of postoperative pain in children with FLACC pain scale in Turkish translation. Turkiye Klinikleri J Anest Reanim 2006;4(1):1-4.

17. Lawshe $\mathrm{CH}$. A quantitative approach to content validity. Pers psychol 1995;28(4):563-75.

18. Ayre C, Scally AJ. Critical values for Lawshe's content validity ratio: revisiting the original methods of calculation. Meas Eval Couns Dev 2014;47(1):79-86. do1: 10.1177/0748175613513808.

19. Boztunç Öztürk N, Eroğlu MG, Kelecioğlu H. Eğitim alanında yapılan ölçek uyarlama makalelerinin incelenmesi. Eğitim ve Bilim 2015;40(178):123-37.

20. Maneesriwongul W, Dixon JK. Instrument translation process: a methods review. J Adv Nurs 2004;48(2):175-86.

21. Hall EOC, Wilson ME, Frankenfield JA. Translation and restandardization of an instrument: The early infant temperament questionnaire. J Adv Nurs 2003;42(2):159-68.

22. Yurdugül H. Ölçek geliştirme çalışmalarında kapsam geçerliği için kapsam geçerlik indekslerinin kullanılması, XIV. Ulusal Eğitim Bilimleri Kongresi, Pamukkale Üniversitesi Eğitim Fakültesi, 28-30 Eylül 2005, Denizli, Bildiri Tam metni.

23. Büyüköztürk Ş, Kılıç Çakmak E, Akgün ÖE, Karadeniz Ş, Demirel F. Bilimsel araştırma yöntemleri. Ankara: Pegem Akademi Yayınları;2008.

24. Yeşilyurt S, Çapraz C. A road map for the content validity used in scale development studies. Erzincan Üniversitesi Eğitim Fakültesi Dergisi 2018;20(1), 251-64.

25. McCarthy C, Hewitt S, Choonara I. Pain in young children attending an accident and emergency department. J Accid Emerg Med 2000;17:265-7. 